\title{
Analysis of Factors Related to Personal Behaviour of Hygiene on the Ship Crew in PT Salam Pasific Indonesia Lines Surabaya
}

\author{
Febrina Putri Raoef, Eka Mishbahatul M. Has*, Deni Yasmara \\ ${ }^{1}$ Department of Soul, Gerontic and Community, Faculty of Nursing, Unversitas Airlangga, Mulyorejo, Surabaya, East Java 60115
}

Received: 06/07/2020

Accepted: 20/09/2020

Published: 20/12/2020

\begin{abstract}
Fulfilment of personal hygiene is needed for individual comfort, safety, and health. Personal hygiene needs are needed both healthy people and sick people. Personal hygiene practices aim to improve health where the skin is the body's first defence line against infection. This study aims to explain the factors associated with personal hygiene behaviour on the crew at PT Salam Pacific Indonesia Lines Surabaya. This study used a correlational study design with a cross sectional approach. The population in this study was the crew of the ship PT Salam Pacific Indonesia Lines that docked at the Port of Tanjung Perak Surabaya as many as 7 ships with a total sample of 104 respondents. The independent variables measured included knowledge, attitudes, infrastructure and friend support, and the dependent variable measured was personal hygiene behaviour. Research data collection using an instrument in the form of a questionnaire after this was analysed with the Spearman rank statistical test. The results of this study indicate that the level of knowledge has an insignificant relationship $(p=0.876)$ with personal hygiene behaviour, attitudes have insignificant relationship $(p=0.114)$ with personal hygiene behaviour, infrastructure has an insignificant relationship $(\mathrm{p}=0,280)$ with personal hygiene behaviour, and friend support have insignificant relationship $(\mathrm{p}=0,121)$ with personal hygiene behaviour. There was no dominant factor in personal hygiene behaviour on the crew at PT SPIL Surabaya.
\end{abstract}

Keywords: Knowledge, Attitude, Friend support, Facilities and infrastructure, Personal hygiene, Crew members

\section{Introduction}

Personal hygiene is a treatment conducted personally to maintain good health both physically and psychologically. The fulfilment of self-care is influenced by various factors, including culture, social values in individuals or families, knowledge about self-care, and perception. The fulfilment of personal hygiene is necessary for individual comfort, safety, and health. Personal hygiene needs are needed both healthy people and sick people. Personal hygiene practices aim to improve health where the skin is the body's first defence line against infection (1). The ship is one of the transportation facilities which is considered as a temporary residential environment that has a relatively long residence time. Every person on board must maintain sanitation and health of the ship such as sanitation facilities, food supply, environmental cleanliness on board, and health on oneself. The crew who live on board generally take care of themselves and get the same facilities. Crew activities performed on the ship towards personal hygiene still require attention where the crew still performs behaviours that lead to poor personal hygiene due to lack of knowledge, limited resources, and health education that has not been completed well (2).

Based on the background study, it was found that the activities of the crew on the ship for personal hygiene still needed attention where the crew still took actions that led to adequate personal hygiene due to lack of knowledge, limited resources, and others. This also happened at PT Salam Pacific Indonesia Lines in Surabaya where the crew still performed poor personal hygiene as evidenced by the large number of crew members suffering from diseases due to poor personal hygiene. Previous studies conducted by researchers on 3 May 2017 obtained secondary data obtained from PT SPIL Surabaya showed that in 2015 as many as 78 crew members with a percentage of $38.3 \%$ experienced health problems related to poor personal hygiene, namely shortness of breath $5,4 \%$, infectious diseases $2 \%$, diarrheal disease $5.4 \%$, typhoid disease $3.9 \%$, and cold cough fever $21.6 \%$. In 2016 the incidence increased by 85 crewmembers with a percentage of $40.3 \%$, namely shortness of breath $3.3 \%$, infectious diseases $3.8 \%$, diarrheal disease $6.2 \%$, typhus disease $3.8 \%$, and cold cough fever 23.2\%. In 2017 until April 2017 there were 24 crew members with a percentage of $47.1 \%$, namely $2 \%$ infectious disease, $9.8 \%$ diarrheal disease, $9.8 \%$ typhus disease, and $25.5 \%$ cold cough fever. Personal hygiene is an important thing to do and pay attention because it can affect a person's physical and psychological health. The dominant factor influencing the formation of personal hygiene behaviour is the level of knowledge. Behaviour that is based on knowledge will be better than behaviour that is not based on knowledge (3). This is in accordance with the Preceed-Proceed theory proposed by Lawrence W. Green (1980) which examines the problem of human behaviour and the factors that influence it and how to follow it up by trying to change, maintain, or improve the behaviour in a more positive direction (4). This study aims to analyse the factors related to the personal hygiene behaviour of ship crews at PT SPIL Surabaya or someone whose life is often

Corresponding author: Eka Mishbahatul M. Has, Eka Mishbahatul M.Has, Department of Soul, Gerontic and Community, Faculty of Nursing, Unversitas Airlangga, Mulyorejo, Surabaya, East Java 60115, Email: eka.m.has@ fkp.unair.ac.id 
aboard ships, to see the relationship between personal hygiene behaviour and the potential for resurrection of ship crews at PT SPIL Surabaya.

\section{Method}

This study used a correlational research method with cross sectional approach. The subjects used in this study were 7 ships in the Port of Tanjung Perak Surabaya with a total of 140 crew, the subjects must fulfil the inclusion and exclusion criteria of the study. The inclusion criteria in this study were the crew at PT SPIL Surabaya at the time of the study, age $>20$ years old and willing to participate in the study, while the exclusion criteria in this study were the crew who were not on board. The sampling technique used in this study was Probability Sampling with simple random sampling technique. The independent variables in this study were predisposing factors including knowledge and attitudes of the crew, supporting factors include facilities and infrastructure, and driving factors include friend support. The dependent variable of this study was the personal hygiene behaviour of the crew. The instrument used in this study was a questionnaire guideline with various choices of answers regarding factors related to personal hygiene behaviour on the crew. Interviews were conducted with respondents based on existing questionnaires. The results of this interview would be performed a statistical correlation test by using the Spearman rank to determine the significance of the relationship between the independent variable and the dependent and the degree of significance or significance level was $\alpha=0.05$.

\section{Results}

\subsection{Characteristics of Respondents}

Table 1 showed that most of the crew members have an academic or tertiary education level of 68 people $(65.38 \%)$. Most of the crew members are aged 21-30 years old that is 48 people $(46.15 \%)$

\subsection{Description of Research Variables}

The measured variables in this study were the level of knowledge related to personal hygiene behaviour, attitudes related to personal hygiene behaviour, facilities and infrastructure related to personal hygiene behaviour, friend support related to personal hygiene behaviour, personal hygiene behaviour, and personal behaviour observation hygiene. The following was a description of each variable in tabular form (Table 2). Table 2 showed that most of the 60 respondents $(57.6 \%)$ have sufficient knowledge, 53 respondents $(50.96 \%)$ have positive attitudes, 104 respondents (100\%) complete infrastructure, 53 respondents (50.96\%) support friends positive, 104 respondents $(100 \%)$ had good personal hygiene behaviour, and 104 respondents (100\%) observed that personal hygiene behaviour was sufficient.

Table 1: Demographic characteristics of PT SPIL crew members based on education and age

\begin{tabular}{lll}
\hline Respondent Characteristics & Total & Percentage $(\%)$ \\
\hline Education & & \\
Bachelor & 68 & 65,38 \\
Senior High School & 36 & 34,62 \\
Total & 104 & 100 \\
Age & & \\
$21-30$ years old & 48 & 46,15 \\
$31-40$ years old & 18 & 17,30 \\
$41-45$ years old & 14 & 13,46 \\
$>45$ years old & 24 & 23,09 \\
Total & 104 & 100 \\
\hline
\end{tabular}

Table 2: Distribution of respondents based on research variables of ship crews on PT SPIL Surabaya vessels

\begin{tabular}{|c|c|c|c|}
\hline Measured Variables & Category & $\mathrm{N}$ & $\%$ \\
\hline \multirow{4}{*}{ Knowledge } & Less & 0 & 0 \\
\hline & Sufficient & 60 & 57,6 \\
\hline & Good & 44 & 42,4 \\
\hline & total & 104 & 100 \\
\hline \multirow{3}{*}{ Behaviour } & Negative & 53 & 50,96 \\
\hline & Positive & 51 & 49,04 \\
\hline & Total & 104 & 100 \\
\hline \multirow{3}{*}{ Facilities and Infrastructure } & Incomplete & 0 & 0 \\
\hline & Complete & 104 & 104 \\
\hline & Total & 100 & 100 \\
\hline \multirow{3}{*}{ Friend's Support } & Negative & 51 & 49,04 \\
\hline & Positive & 53 & 50,96 \\
\hline & Total & 104 & 100 \\
\hline \multirow{4}{*}{ Personal hygiene behaviour } & Less & 0 & 0 \\
\hline & Sufficient & 0 & 0 \\
\hline & Good & 104 & 100 \\
\hline & Total & 104 & 100 \\
\hline \multirow{4}{*}{$\begin{array}{l}\text { Observation of personal hygiene } \\
\text { behaviour }\end{array}$} & Less & 0 & 0 \\
\hline & Sufficient & 104 & 100 \\
\hline & Good & 0 & 0 \\
\hline & Total & 104 & 100 \\
\hline
\end{tabular}




\subsection{The relationship between predisposing factors (knowledge and attitudes), supporting factors (facilities and infrastructure), driving factors (friend support) with personal hygiene behaviour, and observation of personal hygiene behaviour}

Table 3 showed that most of the 60 respondents $(57.7 \%)$ had sufficient knowledge with good personal hygiene behaviour. Spearman Rank statistical test results obtained $\mathrm{p}$ value $=0.876(p>0.05)$, then $\mathrm{H} 1$ was rejected which indicated that there was no relationship between predisposing factors (knowledge) with personal hygiene behaviour on the crew at PT SPIL Surabaya. Table 4 showed that most of the 53 respondents $(50.96 \%)$ had a negative attitude with good personal hygiene behaviour. Spearman Rank statistical test results obtained $p$ value $=0.114(p>0.05)$, then $\mathrm{H} 1$ was rejected which indicated that there was no relationship between predisposing factors (attitudes) and personal hygiene behaviour on the crew at PT SPIL Surabaya. Table 5 showed that most of the 104 respondents $(100 \%)$ facilities and infrastructure were complete with good personal hygiene behaviour, i.e. the Spearman Rank statistical test results obtained $p=0.280$ ( $p$ > $0.05)$, then $\mathrm{H} 1$ was rejected which indicated that there was no the relationship between supporting factors (facilities and infrastructure) and personal hygiene behaviour on the crew at PT SPIL Surabaya. Table 6 shows that most of the 53 respondents $(50.96 \%)$ support positive friends with good personal hygiene behaviour. Spearman Rank statistical test results obtained $p$ value $=0.121(p>0.05)$, then $\mathrm{H} 1$ was rejected which indicated that there was no relationship between the driving factor (friend support) and personal hygiene behaviour on the crew at PT SPIL Surabaya.

\section{Discussion}

There is no dominant factor in personal hygiene behaviour on the crew at PT SPIL Surabaya. Predisposing factors (knowledge and attitudes), supporting factors (facilities and infrastructure), and driving factors (friend support) have nothing to do with personal hygiene behaviour on the crew at PT SPIL Surabaya. The level of knowledge is influenced by learning. This learning is intended to provide knowledge to the crew about proper personal hygiene behaviour $(5,6)$. Knowledge covered in the cognitive domain has six levels, such as: know, understand, application, analysis, synthesis, and evaluation. Changes in terms of knowledge about personal hygiene behaviour are preceded by a person's perception of what will be lived, thus perceptions arise related to the level of knowledge obtained from information. There are several internal factors that exist in individuals, families, groups, or communities that make it easier for individuals to behave in a healthy manner, one of them is the knowledge they have $(7,8)$.

Table 3: Distribution of the relationship of predisposing factors (knowledge) with personal hygiene behaviour

\begin{tabular}{|c|c|c|c|c|c|c|c|c|}
\hline \multirow{3}{*}{ Predisposition Factors (Knowledge) } & \multicolumn{6}{|c|}{ Behaviour } & \multirow{2}{*}{\multicolumn{2}{|c|}{ Total }} \\
\hline & \multicolumn{2}{|c|}{ Less } & \multicolumn{2}{|c|}{ Sufficient } & \multicolumn{2}{|c|}{ Good } & & \\
\hline & $\mathrm{N}$ & $\%$ & $\mathrm{~N}$ & $\%$ & $\mathrm{~N}$ & $\%$ & $\mathrm{~N}$ & $\%$ \\
\hline Less & 0 & 0 & 0 & 0 & 0 & 0 & 0 & 0 \\
\hline Sufficient & 0 & 0 & 0 & 0 & 60 & 57,7 & 60 & 57,7 \\
\hline Good & 0 & 0 & 0 & 0 & 44 & 42,3 & 44 & 42,3 \\
\hline Total & 0 & 0 & 0 & 0 & 104 & 100 & 104 & 100 \\
\hline
\end{tabular}

$\mathrm{p}=0.876 \mathrm{r}=0.1909$

Table 4: Distribution of the relationship between predisposing factors (attitudes) and personal hygiene behaviour

\begin{tabular}{|c|c|c|c|c|c|c|c|c|}
\hline \multirow{3}{*}{ Predisposition Factors (Behaviour) } & \multicolumn{6}{|c|}{ Behaviour } & \multirow{2}{*}{\multicolumn{2}{|c|}{ Total }} \\
\hline & \multicolumn{2}{|c|}{ Less } & \multicolumn{2}{|c|}{ Sufficient } & \multicolumn{2}{|c|}{ Good } & & \\
\hline & $\mathrm{N}$ & $\%$ & $\mathrm{~N}$ & $\%$ & $\mathrm{~N}$ & $\%$ & $\mathrm{~N}$ & $\%$ \\
\hline Negative & 0 & 0 & 0 & 0 & 53 & 50,96 & 0 & 0 \\
\hline Positive & 0 & 0 & 0 & 0 & 51 & 49,04 & 104 & 100 \\
\hline Total & 0 & 0 & 0 & 0 & 104 & 100 & 104 & 100 \\
\hline$p=0,114 \quad r=0,1909$ & & & & & & & & \\
\hline
\end{tabular}

Table 5: Distribution of the relationship of supporting factors (facilities and infrastructure) and personal hygiene behaviour

\begin{tabular}{|c|c|c|c|c|c|c|c|c|}
\hline \multirow{3}{*}{ Supporting Factors } & \multicolumn{6}{|c|}{ Behaviour } & \multirow{2}{*}{\multicolumn{2}{|c|}{ Total }} \\
\hline & \multicolumn{2}{|c|}{ Less } & \multicolumn{2}{|c|}{ Sufficient } & \multicolumn{2}{|c|}{ Good } & & \\
\hline & $\mathrm{N}$ & $\%$ & $\mathrm{~N}$ & $\%$ & $\mathrm{~N}$ & $\%$ & $\mathrm{~N}$ & $\%$ \\
\hline Incomplete & 0 & 0 & 0 & 0 & 0 & 0 & 0 & 0 \\
\hline Complete & 0 & 0 & 0 & 0 & 104 & 100 & 104 & 100 \\
\hline Total & 0 & 0 & 0 & 0 & 104 & 100 & 104 & 100 \\
\hline
\end{tabular}

Table 6: Distribution of the relationship between push factors (friend support) and personal hygiene behaviour

\begin{tabular}{|c|c|c|c|c|c|c|c|c|}
\hline \multirow{3}{*}{ Supporting Factors } & \multicolumn{6}{|c|}{ Behaviour } & \multirow{2}{*}{\multicolumn{2}{|c|}{ Total }} \\
\hline & \multicolumn{2}{|c|}{ Less } & \multicolumn{2}{|c|}{ Sufficient } & \multicolumn{2}{|c|}{ Good } & & \\
\hline & $\mathrm{N}$ & $\%$ & $\mathrm{~N}$ & $\%$ & $\mathrm{~N}$ & $\%$ & $\mathrm{~N}$ & $\%$ \\
\hline Negative & 0 & 0 & 0 & 0 & 51 & 49,04 & 0 & 0 \\
\hline Positive & 0 & 0 & 0 & 0 & 53 & 50,96 & 104 & 100 \\
\hline Total & 0 & 0 & 0 & 0 & 104 & 100 & 104 & 100 \\
\hline $\mathrm{p}=0,121 \quad \mathrm{r}=0,1909$ & & & & & & & & \\
\hline
\end{tabular}


The results of the data analysis showed knowledge of good personal hygiene behaviour in the respondents, this was related to several factors that influenced the respondents' knowledge such as education and age. Age also influences one's comprehension and mind-set, because the older you get, the more your comprehension and thought patterns will develop hence the knowledge you get is better (9).

There are several supporting factors that exist in individuals, families, groups, or communities that make it easier for individuals to behave healthy one of which is the availability of facilities and infrastructure. Health resources are all the hardware and software needed to support the implementation of health efforts (10). Availability of facilities and infrastructure included in health resources. Health facilities function as a place for health services (curative, preventive, promotive, and rehabilitative) (11,12). Implementation of health-oriented development requires various types of health workers who have the ability to conduct health efforts with a healthy paradigm that is more priority to efforts to improve and maintain health and prevent disease. Disease prevention activities also require health resources $(13,14)$. The availability of facilities and infrastructure is very supportive for the crew to always maintain personal hygiene behaviour. The ship environment is the main place for the crew to spend their daily activities. The provision of facilities from the ship and the company in the form of facilities and infrastructure to conduct the personal hygiene required by the crew is very good. The factor that allows this to happen is due to the attitude of the individual person that underlies a person to behave well toward personal hygiene behaviour. As well as individual experiences related to how to maintain good personal hygiene. Social groups in the environment can influence personal hygiene behaviour. During childhood, they get learning about personal hygiene from parents such as family habits, the number of people who are at home, and facilities in the house. As time progresses, the transition from childhood to adulthood can recognize adequate personal hygiene practices (15).

The results of this study prove that the realization of personal hygiene behaviour has nothing to do with the support of friends. This is due to the crew have learned lessons about personal hygiene since childhood and know adequate personal hygiene practices. The mechanism if the individual has been able to do something right automatically, or something is already a habit, then the individual has reached the third level of practice (16). Adoption is a practice or action that has developed well. This means that the action has been modified without reducing the correctness of the action (17). Further action is needed to improve behaviour related to maintaining personal hygiene / personal hygiene and counselling is needed related to personal hygiene behaviour that is good and right thus the crew can practice it every day and reduce the risk of health problems for the crew.

\section{Conclusion}

There is no dominant factor in personal hygiene behaviour on the crew at PT SPIL Surabaya. Predisposing factors (knowledge and attitudes), supporting factors (facilities and infrastructure), and driving factors (friend support) have nothing to do with personal hygiene behaviour on the crew at PT SPIL Surabaya.

\section{Ethical issue}

Authors are aware of, and comply with, best practice in publication ethics specifically with regard to authorship (avoidance of guest authorship), dual submission, manipulation of figures, competing interests and compliance with policies on research ethics. Authors adhere to publication requirements that submitted work is original and has not been published elsewhere in any language.

\section{Competing interests}

The authors declare that there is no conflict of interest that would prejudice the impartiality of this scientific work.

\section{Authors' contribution}

All authors of this study have a complete contribution for data collection, data analyses and manuscript writing.

\section{References}

1. Tohit NFM, Rampal L, Mun-Sann L. Prevalence and predictors of pediculosis capitis among primary school children in Hulu Langat, Selangor. Med J Malaysia. 2017;72(1):12-7.

2. Wang Q, Dong L, Jian Z, Tang X. Effectiveness of a PRECEDEbased education intervention on quality of life in elderly patients with chronic heart failure. BMC Cardiovasc Disord. 2017;17(1):17.

3. Lewis GH, Vaithianathan R, Hockey PM, Hirst G, Bagian JP Counterheroism, common knowledge, and ergonomics: concepts from aviation that could improve patient safety. Milbank Q. 2011;89(1):4-38.

4. Barry PC. Shower personal hygiene system. Google Patents; 1993.

5. Hommann E. Hand-held appliance for personal hygiene. Google Patents; 1987.

6. Setyowati D, Mubawadi T, Mirasa YA, Purwanto D, Amin M, Utsumi T, et al. Molecular epidemiology of hepatitis A outbreaks in two districts in Indonesia in 2018 : Same subtype, but different strains. 2019;1-8.

7. Idowu OA, Rowland SA. Oral fecal parasites and personal hygiene of food handlers in Abeokuta, Nigeria. Afr Health Sci. 2006;6(3):160-4.

8. Setyowati D, Prasetyo B, Husada D. Differences in Growth of Children with Autism and Normal in Surabaya, Indonesia. Indian J Public Heal Res Dev. 2019;10(7):899.

9. Cook CD, Steinhardt MJ. Convenience kit for dispensing different personal hygiene components. Google Patents; 1993.

10. Pfenniger P, Fischer F, Huber B. Personal hygiene device. Google Patents; 2007

11. Alam N, Wojtyniak B, Henry FJ, Rahaman MM. Mothers' personal and domestic hygiene and diarrhoea incidence in young children in rural Bangladesh. Int J Epidemiol. 1989;18(1):242-7.

12. Dewi DNSS, Mertaniasih NM, Ozeki Y, Artama WT, Niki M Tateishi Y, et al. Characteristic profile of antibody responses to PPD, ESAT-6, and CFP-10 of Mycobacterium tuberculosis in pulmonary tuberculosis suspected cases in Surabaya, Indonesia. Brazilian J Infect Dis. 2019;23(4):246-53.

13. Muinde OK, Kuria E. Hygienic and sanitary practices of vendors of street foods in Nairobi, Kenya. African J Food, Agric Nutr Dev. 2005;5(1).

14. Sari NIP, Mertaniasih NM, Maruyama F. Application of serial tests for Mycobacterium tuberculosis detection to active lung tuberculosis cases in Indonesia. BMC Res Notes. 2019;12(1):313.

15. Perry, Potter. Buku Ajar Fundamental Keperawatan. Jakarta: EGC; 2009.

16. Bruhn JG. Life-style and health behavior. In: Health behavior. Springer; 1988. p. 71-86.

17. Gregory GD, Leo M Di. Repeated behavior and environmental psychology: the role of personal involvement and habit formation in explaining water consumption 1. J Appl Soc Psychol. 2003;33(6):1261-96 